\title{
Resisting discriminatory immigration procedures and practices in the UK and Pakistan: a discourse-ethnographic approach to exploring migration literacies
}

Book or Report Section

Accepted Version

Capstick, T. (2020) Resisting discriminatory immigration procedures and practices in the UK and Pakistan: a discourseethnographic approach to exploring migration literacies. In: Sociolinguistic perspectives on migration control: language policy, identity and belonging. Language, mobility and institutions. Multilingual Matters, Bristol, UK, pp. 41-63. ISBN 9781788924689 doi: https://doi.org/10.21832/9781788924689004 Available at http://centaur.reading.ac.uk/98583/

It is advisable to refer to the publisher's version if you intend to cite from the work. See Guidance on citing.

Identification Number/DOI: https://doi.org/10.21832/9781788924689-004 <https://doi.org/10.21832/9781788924689-004> 
All outputs in CentAUR are protected by Intellectual Property Rights law, including copyright law. Copyright and IPR is retained by the creators or other copyright holders. Terms and conditions for use of this material are defined in the End User Agreement.

\section{www.reading.ac.uk/centaur}

\section{CentAUR}

Central Archive at the University of Reading

Reading's research outputs online 


\section{Resisting discriminatory immigration procedures and practices in the UK and Pakistan: a discourse ethnographic approach to exploring migration literacies}

\section{Introduction}

The central theme running through this volume is discrimination and the myriad ways language provides opportunities to resist or subvert it. This chapter contributes to this discussion of migrants' opportunities to counter discriminatory discourses by exploring non-institutional contexts and touching on informal sectors of the economy where the migrants in this study work. Settings include homes in Pakistan and the UK, a solicitor's office, a take-away restaurant and taxi office in Lancashire UK, and the online spaces of Facebook which connect family members in these settings and beyond. The approach taken draws on work developed by Duchene et al. (2013) exploring migration and social inequalities by focusing in particular on the work of Ahearn (2012: 278) and the socioculturally mediated capacity to act by exploring the strategies that migrants use to resist discriminatory discourses. By combining approaches from the Discourse Historical Approach (DHA) in Critical Discourse Studies (CDS) with work on literacy as social practice, a framework is assembled for understanding literacy practices as sites of resistance and 'the varying opportunities migrants have to negotiate position, agency, and resistance through language' (Duchene et al., 2013: 10). How migrants negotiate resistance at the family level has received less attention particularly when looking at migrant families' practices before and after migration. This chapter explores one family's attempts to resist and subvert discriminatory immigration procedures and practices by examining their access to literacy in a range of sites and how this access presents opportunities to counter discrimination.

Literacy in this study is seen as social practice, applied in different contexts to meet different purposes. In the vignettes which follow the purposes are all related to migration. Taking this approach meant exploring different activities involving reading and writing in the everyday lives of family members and relating these practices to individuals' migrations. These practices are embedded in the histories of families connected by chain migration between Pakistan and the UK as well as in the contingent and ever-changing context of immigration policies in the UK. Participant observation is an important aspect to the ethnographic perspective adopted here. This observation necessitated taking part in activities with family members in (Mirpur) Pakistan and (Lancashire) UK as well as observing them and asking about individuals in interviews. As a result, an extensive range of data was generated from many different locations in Mirpur and Lancashire. In collecting data, the challenge was avoiding what, in his critique 
of Critical Discourse Analysis (CDA), Blommaert (2005) refers to as prima facie ethnographies, which he describes as the dense descriptions of institutions and contexts which are used as framing devices in CDA analyses. Blommaert goes on to suggest that these a priori contextualisations are based on assumptions rather than evidence, which makes them a problematic starting point for discourse analysis. For these reasons, the theoretical framework for this study combines the social practices approach to the study of literacy with the DHA. The insider perspective, which is a central aim of a literacy practices approach, was integrated with CDS's critical perspective on society. This meant that the framework was put to use to analyse social problems related to literacy and migration through the systematic analysis of texts as well as the practices which surround these texts.

The scope of this study went beyond an analysis of the texts of immigration and explored the literacy practices that link texts with institutions, social structures and discourses about migration. This approach was taken because, for migrants arriving in a new location, knowledge of the language practices as well as of the appropriate interactional and interpretive strategies is key for negotiating access to work and the organisation of family life. Interviews and participant observation were carried out in a range of settings in homes and workplaces in Pakistan and the UK, and methods of analysis drew primarily on discourse analysis in order to identify the linguistic resources migrants use migrants use to subvert the control of powerful social agents both within the Mirpuri community and from within the bureaucratic agencies which regulate immigration. Ahearn (2012: 278) renders this as the 'socioculturally mediated capacity to act, along with strategies to contest and resist'.

\section{Mirpuris in Britain}

The term 'community cohesion' emerged out of the Cantle report (Home Office, 2001) in the UK, which was written in response to the May 2001 'riots' which saw young White men fighting young Pakistani and Bangladeshi men in East Lancashire, West Yorkshire and Greater Manchester. It is in this part of Lancashire that Usman, the key respondent in this study, now lives. Since the 2001 'riots' in the northern mill towns, the terror attacks in the US on 11 September 2001 ('9/11') and in the UK on 7 July 2005 ('7/7'), British Muslims have experienced intense media and political scrutiny which have become central to public debates about Pakistani Muslims in the UK and their lack of desire or ability to cohere with their Anglo neighbours. The Cantle report introduced the concept of 'parallel lives' into the debate and the 
subsequent chain of discourse which, Blackledge (2005) argues, began with the riots. In 2004, David Goodhart argued that seventeen of Britain's twenty most segregated towns are in the north and northwest of England, in particular the Pennine towns of east Lancashire and West Yorkshire (the towns in which the research participants in this study live).

Blackledge (2005) has traced how this portrayal of minority groups links minority languages with threats to democracy, civil disorder and notions of citizenship and nationhood. He argues that these arguments travel along chains of discourse until they gain the legitimacy of the state and are normalized in laws such as the Nationality, Immigration and Asylum Act (2002) which Blackledge links discursively to the riots in 2001. This legitimation is granted by the state but is then taken up in non-institutional as well as institutional settings as it sets in motion particular ways of speaking about migrants, ways which are in turn taken up by migrants as well as nonmigrants. Until the Nationality, Immigration and Asylum Act (2002), spouses were exempt from the requirement for British citizenship applicants to have 'sufficient knowledge of the English, Welsh or Scottish Gaelic language', which was introduced in the British Nationality Act 1981 (Blackledge, 2005). The 2002 Act extended this requirement to people applying for naturalization on the basis of marriage and introduced a requirement that applicants should demonstrate knowledge about life in the UK. In 2005 the 'Life in the UK Test' became a requirement for those applying for British Citizenship; then, in 2007, this requirement was extended to applicants for indefinite leave to remain in the UK. However, it was not until legislation introduced in November 2010 that visa applicants from non-European Economic Authority countries had to provide evidence of having passed an English language test prior to applying for a visa to the UK. These tests discriminate against the many applicants who do not have access to quality English language courses or test preparation courses in their home countries (Capstick, 2011).

The many young British Pakistanis marrying into Mirpuri families are among those most affected by the legislation. A report produced for the Department for Communities and Local Government in 2009 on the Pakistani Muslim community in England stated that "[t]here are no accurate figures available but it is estimated that 60 per cent of the Pakistani population is from the Mirpur District" (2009: 6)

In a previous study, Shaw argues that for these young British men and women transnational marriage enables kinship responsibilities to be met through the diversification of assets such as links to property in Pakistan as well as the UK (Shaw, 1988). Also, in his study of migration and the Mirpuri economy, Ballard (2008) argues that it is economic remittances that have had 
the greatest impact on Mirpuri society, given the many millions of pounds that have been remitted to the area over the last 60 years. However, Bolognani (2014) argues that British Mirpuris relationship with Mirpur has shifted in the past ten years towards the idea that 'back home' offers the potential for exploitation for social or economic gain and a relationship that connotes excessive traditionalism. In their recent work, Charsley and Bolognani (2017: 45) suggest that the portrayal of the marriage migrant or 'freshie' represents an attempt by Britishborn Pakistanis to clarify cultural boundaries and assertions of belonging. In these representations, distancing by British Pakistanis from their counterparts from South Asia is made all the more tense by close kinship ties and the ongoing practice of transnational marriage. The authors argue that intra-ethnic discrimination of this kind is not unique to British Pakistanis. In their analysis of youtube comedy videos mocking recent arrivals from Pakistan, the authors demonstrate how the interpretations of the 'freshie' centre on 'internalized racism, displacing of stigma and attempts to negotiate local hierarchies of belonging' (2017: 45).

Others have documented the category of 'fresh off the boat' (see Pyke \& Dang, 2003; Shankar, 2008), while McAuliffe (2008) has shown how those in this category often lack fluency in the language of the country to which they are migrating. Realigned gender hierarchies in the UK homes of new migrants mean that male migrants may not necessarily look forward to becoming heads of households in Britain (Ahmed, 2008), whilst those arriving as husbands of British Pakistani women may find themselves in subordinate positions in domestic relations of power (Charsley, 2005). Also, the contrast with the 'freshie's' supposed dubious immigration status emphasizes British Pakistanis' own ambiguous entitlement to British citizenship. Amid the heightened problematisation of British Muslim identities in the wake of 9/11 and the 2001 riots, and with British national identity increasingly marked as white, British Pakistanis place increasing emphasis on citizenship as a form of identity and belonging (Hussain \& Bagguley, 2005).

\section{Theoretical orientations}

The theoretical framework for this chapter draws on the literacy studies and CDS traditions. This is because both traditions have an interest in the ways in which power dominates spaces and institutions and how resistance is linked to processes of both regulation and contestation. Issues of power and resistance are explored here in the discourses of immigration produced by migrants themselves rather than in the discourses of the social actors who discriminate against them. This study is part of the recent move towards critical sociolinguistic studies (Blommaert, 2012; Coupland, 2010; Heller, 2010) and shares the view that the settings under investigation 
are made up of permeable boundaries, shaped by activities, individuals, institutions and discourses which provide countless opportunities to remain open and flexible (Duchene et al., 2013; Marcus, 2005). Furthermore, following Duchene et al. (2013), single-site settings and institutional interactions in those settings are not seen as autonomous events with added contextual information added-on; rather, the approach I take looks across these settings, activities and individuals by investigating the ways in which discourses circulate and are recontextualised (Bauman \& Briggs, 1990; Duchene et al., 2013).

In this way, the methodological approach I take has much in common with the work of Blackledge (2005). In this study, Blackledge analyses the connections that were made between civil unrest in towns in northern England in 2001 and, at the end of the following year, the introduction of the Nationality, Immigration and Asylum Act by the UK government. This new legislation meant that the spouses of British citizens had to demonstrate proficiency in English if they wished to apply for British citizenship. Blackledge identified complex chains of discourse which revealed that political actors' attitudes towards the violence in the northern towns reflected their view that some Asian residents' inability to speak English was a contributory factor to the violence. Minority language use in this part of the UK and its links to the Mirpur division of Azad Kashmir in Pakistan was taken up as a significant theme in work I carried out for my $\mathrm{PhD}$, which explored the language and literacy practices which bind together specific parts of Pakistan and the UK (Capstick, 2016). I refer to this PhD work as the broader study. New data from that research as well as data from the broader study are analysed again in this chapter in order to examine in greater depth how migrants counter discriminatory discourses in their literacy practices. When the key respondent in this study, Usman, started work in a take-away restaurant two months after his arrival in the UK, he told me that there was conflict between the men he described as 'British borns' - men of Pakistani heritage born and raised in the UK - and those born in Pakistan. It is the linguistic dimension of this discrimination on which the following vignettes focus.

To examine how Usman counters this discrimination I have put together a multi-disciplinary theoretical framework which at its core takes a critical approach to investigating language and power. Following Chilton et al. (2010: 491) I take this to mean 'making explicit the implicit relationship between discourse, power and ideology, challenging surface meanings, and not taking anything for granted' as well as being reflexively self-critical. I understand this as part of the way that ethnographers think about reflexivity when addressing the ways in which researchers influence the conditions of the study and affect knowledge production in the 
research settings. This is crucial when ethnographic information on the context and individuals involved in the study is part of the detailed analysis of interactions. When the focus is on the detailed ways language and literacy are seen as valuable resources for resistance in the context of immigration, there are serious consequences for the participants in the study in terms of how discrimination is produced and re-produced throughout these encounters. As a participant observer in some of these encounters, the researcher must then attend to how his or her own discourses influence the observations of the setting and how these are written up in the final analysis.

\section{Resistance in language and literacy resources}

Work on resistance, language and literacy is brought together in this study to understand how migrants counter discourses and construct alternative identities to those portrayed in antiimmigration discourses. In Holly and Meinhof's (2013) work, attention is paid to what it means to claim a language as a resource. Resistance is linked to the different aspects in which language operates as a means of countering domination. In their study, this approach foregrounds the contestation that social actors in Germany take to dominant discourses of integration which are common in public spaces. Their findings demonstrate how these discourses on immigration have become the object of positioning for migrant communities that often distance themselves by criticising it and contesting its ideological foundation, but also they tend to adopt some more subtle stance taking which embraces the dominant discourse (Meinhoff \& Holly, 2013). Thus, resistance takes the form of counter-discourses which nuance and reconfigure the official and dominant discourse on integration (ibid).

In the vignettes which follow below I begin by looking at how family members in my study also seek to reconfigure official and dominant discourses when they appropriate the discourses of the visa application system. I see this as a contribution to what Holly and Meinhof describes as resistance as action through language (2013: 17). This approach has been taken up across different studies as a means to understand the role of language in relation to migration, institutions and work. For example, Holly and Meinhof (2013) focus on how action can be seen in discursive terms, where speaking out and taking a stance vis-à-vis integration is seen as a way of resisting political correctness. They show how taking a stance in this way is a way of 'exercising one's own agency by positioning oneself and creating new forms of allegiance'. In the following vignettes the forms of allegiance Usman develops in the months before and after his migration to the UK are identified. Social networks in the UK as well as in Pakistan are all 
made up of significant allegiances for Usman, his friends and family in the transnational network.

In order to understand how Usman and his family members do this, I draw on the texts of their everyday life as well as the institutional texts of immigration. Work in literacy studies takes practices as its central viewpoint in the study of texts, 'encompassing what people do with texts and what these activities mean to them' (Barton \& Hamilton, 2000: 9). However, Barton and Hamilton (2000) claim that practices are neither accidental nor random but are given their structure by institutions. This includes social institutions, such as the family, education and religion. Bureaucratic institutions, which are more formally structured through rules and procedures, documentation and penalties, are also part of this investigation as migrants regularly come into contact with these institutions when attempting to migrate to the UK from Pakistan. Consequently, an important part of the study was the extent to which institutions, with the power to shape literacy, both supported dominant literacy practices while suppressing vernacular literacy practices. Vernacular here refers to the self-supported and self-sponsored literacies which are less about formal institutional practices and tend more towards what individuals and communities do with literacy away from formal settings. Vernacular literacies may well be less visible but are still a significant aspect of the reading and writing that occur when migrants wish to migrate.

In this study, these vernacular literacies were primarily those related to Facebook postings as these are the contexts in which Usman orients to discourses and constructs identities which counter the discriminatory discourses of 'sham' marriages. The focus was therefore not the discrimination itself but rather on the means by which Usman and his family resist this discrimination as part of their everyday vernacular practices. I take this approach as it provides an understanding of how power patterns social actors' interests and values through institutional relationships between dominant and non-dominant groups as well as within non-dominant groups themselves. Both are central to understanding how power relations pattern literacy practices for migrants in a range of settings. This is where I see literacy as 'resistance as action through language.' Resisting discriminatory immigration practices through the appropriation of dominant literacies for getting a visa highlights the role of language in relation to migration and institutional power.

In the vignettes which follow I examine how migrants perhaps do not go as far as challenging the power relations that make their migration from Azad Kashmir to Lancashire difficult but appropriate the literacies that make their migration successful. Castells argues that 'power is 
exercised by means of coercion (or the possibility of it) and/or by the construction of meaning on the basis of the discourses through which social actors guide their action' (2009: 10). This understanding of discourse and power suggests that relationships play out by threats of violence or through discourses that constitute social action. The focus below is therefore on literacy as resistance to anti-immigration discourses. I do this by looking at how migrants negotiate what Wodak describes as the 'gulfs that separate insiders from outsiders' (1996: 1-2) as migrants use their literacy practices to favour their will over that of the empowered actors.

\section{Methodology}

The data analysed for the broader $\mathrm{PhD}$ study were obtained over an extensive period of fieldwork involving participant observation that was carried out between 2008 and 2012, but the interview data and Facebook postings presented in the focused study of this paper cover a six-month period from January to April 2012. The interviews carried out during this period are marked by Usman's arrival in the UK, through an initial low period where he had little to do, his getting to know his new family, and his starting work. Following Kell, I broke down the ethnographic data collected during this period into a series of strips of approximate timescales (2009) in order to capture the complexity of movement in time and space in the crucial few months after his arrival. I did this so that I could link what Usman was telling me in interviews about his literacy practices to what he was telling me in the interviews about his 'new' life. I transcribed these four two-hour long interviews soon after they took place and used those transcriptions to plan the next field visit to Usman and his family in Lancashire. The Facebook postings were all in response to a total of 16 uploaded photographs. The comments made underneath these photographs were made in Urdu, Mirpuri Punjabi (which Mirpuris refer to as Pahari), Arabic, and Pashto.

After the fieldwork and transcription described above, I selected data for the analysis of textual material from the interviews. I did this using a discourse-analytic method to identify where in the data the participants talked about 'discourse topics' related to migration. Van Dijk describes discourse topics as 'expressed by several sentences in discourse [...] by larger segments of the discourse or by the discourse as a whole' (van Dijk, 1984: 56). In other words discourse topics are the salient themes that underlie the meaning of a series of sentences. As the selected interviews were primarily framed by questions about the participants' literacy practices related to their migration, all the discourse topics relate to migration (the macro-topic). In this discourse there are various sub-topics (Reisigl \& Wodak, 2009). These interviews were analysed quantitatively by looking at references to migration, then by identifying sub-topics 
which were 'put forth by the participants themselves' (Krzyżanowski, 2008: 174). This analysis resulted in the identification of the four discourse sub-topics, i.e. work, kinship, settlement and leaving. Having established these four sub-topics I then coded the interview transcripts using the four sub-topics as categories for data selection. In this way I was able to narrow down the data and focus on those sections related to migration.

\section{Vignette 1: Resisting the sham marriage discourse by appropriating bureaucratic literacies to get a visa}

This section draws on interview data collected in Pakistan with Usman and interview data collected in the UK with Nadia. When Usman received the letter from UKBA informing him that his first visa application was unsuccessful, he was given two reasons. The first reason was that the Entry Clearance Officer (ECO) felt that Nadia was not earning enough money to be able to support Usman if he was unable to find work. The second was that insufficient documentary evidence had been provided to demonstrate that Nadia and her first husband Zeeshan were divorced. Therefore, for the second visa application, Nadia and Usman wanted to 'leave nothing to chance'. The papers were physically carried from Mirpur to Lancashire by a visiting relative and passed to Nadia who employed an immigration solicitor, Fatima, to advise them. Fatima is British Mirpuri and was recommended to Nadia by her brother-in-law in the UK. Although she worked in a town approximately 20 miles from Nadia's home, it was agreed within the family that this was what was needed to get Usman his visa. This is an allegiance that Nadia and other family members developed from within the Mirpuri community. Being able to ask friends of relatives to bring the papers by hand to the UK from Mirpur was further evidence of allegiances within the Mirpuri community.

When I asked Nadia what kind of help she wanted from Fatima, she told me that it was making sure that what Nadia had written about her job and the house fitted with what Fatima knew about a 'good' application. One example of how they drew on Fatima's expertise was when the solicitor told Nadia they must avoid the marriage sounding like, in Fatima's words, 'a sham'. This relates to the dominant discourse in the UK about marriages which are arranged, predominantly between South Asian couples, as a way of maintaining transnational migration. Nadia told Fatima on the phone that she lived with Usman in Mirpur for one month, which Fatima recontextualised and wrote on the form in the voice of Usman as 'we have been cohabiting together and as a result my wife is pregnant. We are committed to remain as a married couple forever'. Fatima felt that this would prove to the UKBA that Nadia and Usman's 
marriage was not a sham. Access to the bureaucratic literacies of immigration can be seen as resistance through language here as, in Usman and Nadia's case, his marriage is not a sham.

Fatima is able to translate the discourse about a 'sham' marriage and provide her clients with access to the register, e.g. 'co-habiting', related to this discourse. The wording is changed to fit the new context. In the first context, Nadia responded orally to the solicitor's questions on the phone and Fatima recast these words when she wrote them down herself on the visa application form, the second context. The immigration solicitor has access to this register because of her knowledge of immigration law, but it is the allegiances among the Mirpuri community that Nadia and Usman tap into that transform Nadia's oral descriptions in English, a process known as register-switching (Baynham \& Masing, 2000; Baynham, 1995). This switching involved Fatima following the conventions of official forms but also invoking the dominant discourses about employment in the first example and about sham marriages in the second. Fairclough (1992) refers to this as (re)formulation, as the immigration solicitor presents an interpretation of the family's earnings where Nadia is recast as a working mother with a home of her own, unlike in the first visa application which portrayed Nadia as an unemployed mother without property.

As Sarangi and Roberts (1999) point out, institutions legitimise, regulate and control resources in bureaucratic encounters, whereas in the literacy practices related to immigration within Nadia's network, literacy is shared and resources are drawn on from across the network, including immigration solicitors. These can therefore be seen as spaces for the appropriation and subversion of the institutional order (Capstick, 2016; Sarangi \& Roberts, 1999). The vignette above provides a productive way of understanding resistance as action. The analysis of both the ways in which language operates as a gatekeeping mechanism to access an immigration visa is intimately linked with language issues. Nadia and Fatima's attempts to recontextualise the wording on the visa forms allow resistance to forms of regulation imposed by the state in this case, in the matter of immigration. In the following vignette, the setting shifts from institutional to non-institutional settings.

\section{Vignette 2: Resisting the 'freshie' identity at work by claiming English as a resource among British-born Mirpuris}

This vignette draws on participant observation and interviews carried out with Usman in the take-away restaurant, taxi office and family home in the UK after he had arrived in the UK. 
Having looked at resistance in the appropriation of dominant discourses about employment and marriage, the following vignette seeks to understand firstly the types of intra-ethnic discrimination migrants face at work and, secondly, resistance as action through literacy when migrants write online. For the analysis of resistance, I bring in the work of Charsley and Bolognani (2017) discussed earlier, in which the authors identify the types of cultural capital that the 'freshies' in their study lack. Firstly, it is their inability to be 'cool' that marks out their portrayal. The authors argue that this lack of dominant cultural capital confines their prospects to both low-status and low-paid work in what they call the ethnic economy. Moreover, they argue that the 'freshie' also lacks the 'tastes and preferences' which would provide them with, in the eyes of young British Pakistanis, cultural status (Charsley \& Bolognani, 2017). This vignette of the 'freshie' as a means of portraying intra-ethnic discrimination is brought together with the dominant discourses of 'sham' marriages above to provide an additional lens through which to examine how Usman, a recent migrant, resists these portrayals in his vernacular literacies. The analysis begins with an extract from an interview with Usman which was carried out with him in the seating area of Pizza Place where he works in Lancashire on April 23, 2014. This was one month before he posted the photograph and comments which will be discussed in the section which follows this vignette. Prior to this part of the interview, Usman and I had been talking about how he was settling into life in Lancashire now that he had started work. Usman was just finishing telling me about working at the taxi office and the positive, yet fledgling, allegiances he was developing with some of the older drivers there.

\section{Interview with Usman four months after his arrival in Lancashire (April 2012)}

Tony: Are they (the drivers) all educated, did some of them not finish school?

Usman: I think some of them, you know, they are just, you know, they are... they are now here now because of the recession. Some of them are educated persons come into taxis otherwise they are all like, you know, been here thirty five years and they just know what's the place and you know.

Tony: And so would you say that in terms of how migration has changed, would you say that some of the guys your age or similar to you in age and more recently arrived, do they have different education than the others or are they the same?

Usman: I don't know, there is er, I don't know the person that I've been talking to you who talks in Urdu from Gujranwala he has a good degree from FFCA you know he has went to good colleges but he doesn't even know one word of English.

Tony: Ah really.

Usman: Yeah cos you know... 
Tony: And what's he doing at Pizza Place?

Usman: He does the... he does the... he does the stuff in the basement like making the pizza bases, making the tomato puree, and marinade the chicken and beef and all that stuff. Making the raw, he does the cooking and the things which is, you know, he makes the things.

Tony: And do you get the feeling that he wants to learn English?

Usman: I don’t know, he never mention anything.

Tony: He doesn't really?

Usman: I tell him just take this newspaper home, just try to read it and just try to watch some of the movies. Just work on the accent, you know, and he says [unclear]. He's not really bothered, not everybody's bothered. We've got three workers who are British borns so I don't like 'em. They just they just use English every time, you know. They can speak Urdu you know but don't speak Urdu. They just use English every time.

Tony: Sorry what do you mean with each other they just use?

Usman: With each other they just use English.

Tony: Why do you think they do that?

Usman: Oh I don't know maybe they just brag you know we [the Mirpuris] don't know English, with me they do English but not with other people.

Tony: Would you say that the people who are born here. Do some of them keep themselves separate to the others?

Usman: No they don't keep it separate, they are good, they are not like they don't talk to us. But they are some politics in politics going on everywhere, but it's just like they are normally good. Some of them are very good and some of them are, I, er... The person who I had a fight with he was just, he was making, you know, fun of me, and I was completely cool with it. But then when I made fun of him he just go bezerk and I just slapped him twice and thrice.

Tony: So he was looking for something, was he looking for something to wind you up do you think?

Usman: I don't know, but he... he was making, what was he saying... I was on the chips and he was [unclear] and he was saying you've just gone out of your mind and this and that. When the work was a bit steady I just asked him, you know, why did you say to me, that I was, you know, that I was er... you know, that I'm out of my mind? I just ask a bit roughly and then you know, he's just gone bezerk, he was swearing at me properly you know.

Tony: What language was he swearing in? 
Usman: Yeah he was swearing in Pahari, yeah. He knows so as long as he did not swear I was alright but as long as he swears, you know, I got hold of his shirt and I just tear the shirt right in half and then I took a slap and two or three kicks and he was just on the ground. But then he was not stopping he was doing the same swearing and all that you know and they just took it [him] away and then, you know, then they fire him. He's not there anymore.

Tony: Do you think he had a problem with you personally or he had a problem generally with...?

Usman: But sometimes when there is a lot of work some workers they just can't cope with the work, you know, they are just like...

Tony: You mean they don't want to work or they are stressed?

Usman: No, but he's from Britain. His mum and dad are well off but they said to him go to a work place, but... but... but... he is the bosses nephew so he said that, you know, he owns the place but that's not the way, you know, if you are a worker you are a worker.

Tony: But they obviously think quite a lot of you?

Usman: Yeah that's why they just fire him. He does this every now and then with everybody but everybody say to him, he's just a nut job, but to me he just provoke me. Nobody ever fights with him because they say he is a kick boxer but he was nothing.

Tony: Would you say that the guys that have come from Mirpur have been more helpful?

Usman: Yeah the guys that who have been from... the... from the, how would you say, that have lead a low life er... not a low life as a personality but low life as a financially, like me, 'cos we were average and everyone else is average and so they know what's the problem of an average man. They don't want any kind of upsets in their life so they all are understanding ...er, but the person who come from a big family and all of that they don't care for... they don't care about [unclear] they just need to do the things to be happen by their life, so I don't know, there's just a bit... but mainly you can live with that kind of person as well as if that person doesn't cross the limits.

\section{Analysis of allegiances and hierarchies at work}

The analysis here focuses on the discursive construction of individuals, groups, and the allegiances and hierarchies they are assigned. Research on the discursive construction of national identity using the DHA has found evidence that marginalised groups such as migrants are the subject of specific discursive strategies in texts from the public sphere (Baker et al., 2008; Blackledge, 2005; Wodak, 2014). In the analysis here I explore how discursive strategies are applied in the ethnographic data collected in Lancashire soon after Usman's arrival in the UK. I explore how these strategies are employed to define the individuals and groups that Usman came into contact with at work to see which allegiances he was able to develop, and 
those he felt he could not due to discrimination, as well as the hierarchies at work and how these were influenced by intra-ethnic discrimination. I analyse the strategies of nomination, predication, argumentation and intensification/mitigation to explore how Usman constructs different connotations with each individual/group.

The interview was held in the home of Usman and Nadia in Lancashire. It took place on April 23, 2012, just over four months after Usman had arrived in Britain. On my previous visit to Usman's home he had been feeling slightly depressed as he had not started work and was bored at home. However, by this interview Usman had started work and was feeling more positive. Prior to the extract discussed here, Usman and I had been talking about his job at the taxi office where he was working on the radio and phone, taking bookings from customers and radioing the drivers to give them details of the pick-up and drop-off. This is evidence of Usman's excellent English as he was dealing with place names, such as Oswaldtwistle, and the Lancashire dialect, which he may have heard in Mirpur but would not have used so regularly before. He described how he was learning quickly that the older Pakistani drivers were 'strict workers' and corrected him if he did something wrong, but that there were also those who liked to 'mess about' with him, hinting that some of the drivers did not make his job easy. The extract above is taken from the part of the interview where I had just started to ask Usman about his second job at the take-away restaurant whose name I have changed to Pizza Place.

The extract is divided into seven sections.

\section{Section 1: Lines 1-5 'they are like, you know, been here 35 years'}

In this section, Usman's use of a perspectivation strategy establishes a dichotomy between the drivers who are more educated and have started working on the taxis recently due to the recession (fewer jobs in other sectors) and those drivers who have been drivers for a long time. There are intertextual links here with other parts of the interview where Usman describes these 'older' taxi drivers as helpful and 'show him the right way'. 'They have been here thirty five years' connotes experience but also marks them out as migrants.

\section{Section 2: Lines 6 - 23 'he doesn't even know one word of English'}

The group above is contrasted with Usman's co-worker at Pizza Place from Gujaranwala, who is described as having good qualifications from Pakistan but, in a referential strategy which aligns good qualifications with being a good speaker of English, uses obvious exaggeration in 'he doesn't even know one word of English': an impossible claim given that Pakistanis codeswitch with English words regularly. The intensification strategy of 'making things' positions 
this man's work 'in the basement' as more menial to Usman's, even though he does not evaluate this negatively. Usman indulges in positive self-presentation when he describes his attempts to help the man learn English. Collectivisation is a salient strategy here as Usman explains 'he's not really bothered, not everyone's bothered', which suggests that there is a group of workers who are not interested in learning English.

\section{Section 3: Lines 23 - 35 'they just use English every time'}

From the evaluative statement 'not everyone's bothered', Usman immediately introduces a new out-group: 'we've got three workers who are British borns so I don't like 'em, they just use English every time, you know they can speak Urdu, you know, but don't speak Urdu, they just use English every time'. In the two years that I had known Usman I had never known him to tell me he did not like someone. Again, Usman draws on collectivisation to describe a group of people who, different to the deictic 'we' which I assume is the rest of the staff at Pizza Place only use English when they could use Urdu. When I probe Usman for the reasons, he adds 'maybe they just brag, you know, we don't know English'. In this, I take the 'we' to mean newly arrived migrants (possibly through marriage migration, from Mirpur) who would fit the 'freshie' persona described by Charsley and Bolognani (2017). Usman uses a nomination strategy I had not heard him use before, 'British born', linking nationality to the attributes which sets this group apart.

Speaking English alone cannot be a problem for Usman as he uses English often. The presupposition is that only using English in that environment, when Urdu is an option, is a strategy taken by the 'British borns' to either set themselves apart or to make comprehension harder for the men that do not understand English well, like the man from Gujaranwala. McAuliffe (2008) suggests that 'freshies' are often found to lack fluency in the language of the country they have migrated to and are, as a result, 'looked down on' due to their poor language skills and inappropriate behaviour. These practices of deflecting stigma onto new migrants have been described as ‘internalized racism’ by Pyke and Dang (2003).

Usman adds that 'with me they do English but not with other people'. This may be positive self-presentation, but as Usman is normally very popular with men and women his age group, and given his excellent English, I take this to mean that he is treated differently than the other men. When I introduce the word 'separate', Usman attempts to mitigate his earlier comment by repeating the adjective 'good', which he attributes to this group, adding that there are 'politics going on everywhere'. Politics could be a euphemism for the power hierarchies that 
Charsley and Bolognani (2017: 49) describe and part of the intra-ethnic boundary-making that the authors suggest has increased since the heightened problematization of British Muslim identities since $9 / 11$ and the 2001 riots. It clearly marks a boundary for Usman, who quickly moves into an unprompted description of a fight with a British-born co-worker straight after this section.

\section{Section 4: 35 - 50 'he just go bezerk'}

Usman's description of events puts the other man firmly in the wrong, suggesting with a predicational strategy that Usman himself had been 'completely cool' with the other man making fun at him. He draws on non-standard varieties of English 'bezerk', a common expression in Lancashire meaning out of control, and the Pakistani English 'I just slapped him twice and thrice' to construct his role in the fight positively. 'Swearing in Pahari' is given as the reason for Usman's violent response. That the man was fired may suggest that Usman was right to stand up for himself, as it would seem from the following section that the man had acted violently before.

\section{Section 5: 51 - 58 'if you are a worker you are a worker'}

The salient part of this section and the next is Usman's construction of a group of workers in Pizza Place which is predicated on socio-economic class and its intersection with being born in the UK. Usman describes his violent co-worker as 'from Britain', with 'well-off' parents and the 'boss's nephew', which, when taken together, attribute privilege to the man. Usman creates a dichotomy next when he takes the view 'if you are a worker you are a worker', which juxtaposes being 'well-off' to being a 'worker'.

\section{Section 6: 59 - 64 'that's why they fire him'}

The co-worker is negatively portrayed as a 'nut job', suggesting that he is mentally unstable.

\section{Section 7: $63-72$ 'low life as a financially like me 'cause we were average'}

Usman continues with the discursive construction of an in-group of workers, using the deictic 'we', who are not privileged in opposition to the out-group, in his terms, of the group he described above. He attributes 'low life' meaning low income (which he refers to as 'financially') and 'like me 'cause we were average' to these men. The phrase 'So they know what's the problem of an average man' characterises these men as having experience and knowledge of life that would set them apart from the privileged group. This in-group 'don't want any kind of upsets', which may well be a euphemism for not wanting to risk their new 
status in the UK. 'Family' is again salient, as in the close-knit community of Mirpuris family connections are central to negotiating work, marriage and stability.

Vignette 3: Vernacular literacy as resistance to intra-ethnic discrimination and dominant discourses of 'sham' marriage

The data drawn on for this vignette is taken from interviews with Usman which were carried out in front of his laptop while looking at Facebook postings. These self-report interviews involved Usman describing language use in the postings as well as how these postings related to his family relationships, friendships and migration. The analysis turns to Usman's literacy practices on Facebook to examine in detail the way he uses language as resistance to discriminatory portrayals of him as a 'freshie' or in a 'sham' marriage by looking at how he represents himself on Facebook when talking about his family. This is an example of how Usman used his online vernacular writing to construct the identity of caregiver to Oman, his step son, on Facebook. As noted earlier, not all communicative resources are the same; they depend on the language modalities (oral and written), for whom a given language constitutes a resource, and what gets accomplished through the communicative act. Thus, I look at Usman's use of literacy in English to explore how he uses language to construct positive identities related to his family. I do this by analysing the communicative resources that Usman and his Facebook friends draw on.

Usman explained in the self-report interview that the photograph was taken in the street outside his home in Lancashire. The photograph is not reproduced here as it identifies the street in which Usman lives. It shows Usman holding his son, Oman. Standing next to them is Usman's stepson, Noor, whose arm is in a bandage. Usman explained to me that Noor had fallen and injured his arm playing cricket. Usman had taken him to the doctor but the doctor had said that the Noor's injury would heal. Zara is Usman's wife's cousin and so a close blood relative to Noor. Zahir is Usman's brother in Mirpur. Fahd and Kamran are friends of Usman's in other parts of Pakistan. By this time Usman also had made friends with over 30 'British-born' Pakistani men and women who were either relatives or friends of Nadia's. Usman, I argue, is aware of this audience as much as he is writing in response to each individual post.

\begin{tabular}{|l|l|l|l|}
\hline Zara Begum & May 28 & $5.09 \mathrm{pm}$ & Wats happened to poor Noor!!!!! \\
\hline $\begin{array}{l}\text { Fahd } \\
\text { Tenacious }\end{array}$ & May 28 & $6.06 \mathrm{pm}$ & My little dude, hi. \\
\hline
\end{tabular}




\begin{tabular}{|l|l|l|l|}
\hline Usman & May 28 & $6.50 \mathrm{pm}$ & He slipped while walking and broke his arm \\
\hline Zara Begum & May 28 & $7.54 \mathrm{pm}$ & Aw bless him.hpe he gets better. \\
\hline Usman & May 28 & $11.18 \mathrm{pm}$ & $\begin{array}{l}\text { He is better now been through operation he is } \\
\text { good now }\end{array}$ \\
\hline Kamran & May 28 & $11.19 \mathrm{pm}$ & nice picture.... \\
\hline Zahir & May 29 & $8.56 \mathrm{am}$ & mashallah!!!nice photo bhai \\
\hline Fahd & June 1 & $1.21 \mathrm{pm}$ & Father take care of him ok nae to.... \\
\hline
\end{tabular}

Table 1: 'Poor Noor' Facebook comments

\section{Resistance as action through vernacular literacy}

In the third line, Usman addresses Zara's question in standard British English and continues with English throughout the interaction, though not always British English. In his next posting, Usman moves between standard British English and Pakistani English. Despite the powerful ideology of Standard British English language proficiency, Usman draws from the Pakistani variety of English. I found that the English that is used by first-generation Mirpuri migrants is looked down on by the non-Mirpuri British Pakistanis interviewed for the wider PhD study. Mirpuri migrants' English, like Mirpuris themselves, was described as low class and rough by interviewees from non-Mirpuri Pakistani participants interviewed in the broader PhD study of migration literacies in Pakistan and the UK (Capstick, 2016). British Mirpuris' use of Pakistani English is not one of the language practices associated with immigrant groups who "no longer represent backward looking traditions' (Blackledge \& Creese, 2010: 28) but rather marks the recent migrant as a 'freshie'.

Usman's brother, Zahir, in contrast to the previous monolingual English practices, posts a comment which draws from standard Arabic, English and Urdu. This contrast is intensified by the topic of his posting, which thanks God, presumably not for Noor's injury, but most likely for the blessing of a son for Usman. Zahir and Zara are drawn to different people in the photograph and they draw from their different language experiences to signal this. While 'Thanks be to God!' is written in Arabic, Zahir uses English to comment 'nice photo', and Urdu to address his brother respectfully. As with many of the findings from Blackledge and Creese's study of multilingualism in the homes of the students of the complementary schools they were researching, this is the usual unmarked multilingualism of English, Arabic and the 
first language. In their study they found that these languages 'enjoy a flexible and nonconflictual co-existence' (2010: 33), as evidenced here by Zahir.

For the posting by Fahd Tenacious, Usman's friend, Usman felt that the 'little dude' he was referring to was Oman, not Noor. This would have meant Fahd Tenacious, like Zahir, had chosen neither to comment on the image of Noor with his arm in a sling nor to respond to Zara's exclamatory statement in the opening line. Responding to Zara online, Usman explained that Noor had 'slipped while walking and broke his arm'. Perhaps Usman's priority is to ease Zara's concern, which it does. Her deviant spelling 'hpe he gets better soon' is the second example of her drawing from abbreviated spelling in British English. Kamran, Usman's youngest brother's karate teacher posts from his home in Azad Kashmir 'nice picture', drawing from his English language practices. This would again suggest a response to the photograph's inclusion of Oman rather than a reference to Noor's arm, which would not warrant the words 'nice picture'.

The posts end, Usman felt, with Fahd Tenacious referring to Usman as a father. Fahd Tenacious posts in English 'take care of him' and then 'o to no' in Urdu, which means 'or else...'. This is the most direct reference to Usman's identity as a father in the online data. Fahd, in Mirpur, chooses to use both English and Urdu here. English may signal Usman's identity as the father of a British English-speaking son. But it is unclear why Fahd would then turn to Urdu to issue his warning; perhaps it signals Usman's Pakistani identity alongside his new identity as a father.

Usman's Facebook writing here, I argue, comes at a significant stage in the negotiation of his identities as a father, husband and stepfather. It is important not to lose sight of the photograph to which these comments relate. Having looked through his other profile pictures, this appeared to be the first picture including Noor posted by Usman, and thus it may well have been the first time he went public with his stepson online, a further negotiation of his new identity as stepfather. Both photograph and language choice help Usman express how he wants to be seen by his Facebook 'friends' in Lancashire, Mirpur and beyond. Specifically, when he responds in British Standard English to Zara's question with the declarative 'He slipped while walking and broke his arm.' Here, Usman, having already positioned himself as a care-giver by posting a photograph with his sons, emphasizes this identity by responding with an explanation of how Noor had the accident. Usman's writing displays a high level of grammatical competence. The clause structure, which is made up of three verbal groups followed by one nominal group, is clear and demonstrates a clear position on the issue of what happened. Highlighting Usman's 
competence here is important, as his careful grammatical construction of the line, I argue, illustrates his desire to belong to the collective of British Mirpuris, like Zara, who are fluent in British English.

Usman takes up Zara's point about Noor getting better and assures her that 'He is better now been through operation he is good now.' Although he chooses not to use punctuation between clauses, his arguments are effectively grouped together and respond to Zara's initial concern by emphasising that Noor is well again. Usman omits the auxiliary verb 'has' and the indefinite article 'an' when he explains that Noor has 'been through operation', although he still displays considerable grammatical competence when writing in formal English. The sentence begins with a present tense verbal group which sets up the reference time for the story, but the next verbal group, the embedded clause 'been through operation', uses the perfect tense to describe what occurred in the past, before the final verbal group returns to the present with 'he is good now'. In the language of Usman's inheritance, Pakistani English, the use of the phrasal verb 'been through' collocates with 'operation' rather than 'have an operation' in British English. The narrative is told using present tense forms but with an embedded clause in a past tense. Usman holds back from introducing the operation until the second clause as he manipulates the sequence of events by changing their order to foreground the fact that Noor is better. This, I argue, is central to Usman's goal of convincing Zara he is a responsible stepfather. The choice of verb forms is an important part of this narrative technique whereby Usman positions himself as a care-giver. Here, the past tense establishes two points along a timeline: a time utterance and a time reference. Here, the time utterance is clear, but the reference to time, 'been through', is unclear and is made even less clear by the missing auxiliary verb in order to emphasize that Noor is better. Auxiliaries conventionally accompany lexical verbs in order to provide more information about how the process is to be interpreted, although Usman omits this information about the past and continues to the present point, foregrounding Noor's recovery.

In the analysis above, Usman draws on literacy in different varieties of English to demonstrate that he is a capable stepfather to Noor and a reliable new member of the family. He does this as a response to Zara, who is a blood relative to Noor, while also making these comments available to many of his Facebook friends from across his wife's social network. The discussion here benefits from seeing Usman's literacy practices in the same light as Sabate i Dalmau sees the migrants in her study articulate bottom-up resistance against discrimination, that these are examples of a 'window into how migrants, through language, mobilise resistance through their own linguistics capitals and in their own self-regulated discursive spaces' (2013: 249). 


\section{Conclusion}

In this chapter my aim was to look across different sites in Pakistan and the UK to explore what Ahearn has described as the 'socioculturally mediated capacity to act, along with strategies to contest and resist' (2012: 278) when migrants face discrimination from inside and outside their immediate community. I was particularly interested in what it means to claim a language as a resource in these settings and how those resources will be taken up in different ways at different times and with different family members. By taking this approach I found that resistance is linked to the different aspects in which language operates as a means of countering domination as different languages and literacies are taken up with different friends, family and workmates. This is because, as Holly and Meinhof have shown, taking a stance is a way of exercising one's own agency by positioning oneself and creating new forms of allegiance (2013). Creating new forms of allegiance was an important orientation in the vignettes which were explored as I set out to identify the forms of allegiance Usman developed in the months before and after his migration to the UK.

The three vignettes above provide a productive way of understanding resistance as action and allegiance. In the first account about appropriating dominant literacies to challenge the sham marriage discourse, the analysis revealed the ways in which language operates as a gatekeeping mechanism to access an immigration visa. Nadia and Fatima's attempts to recontextualise the wording on the visa forms allowed the family to resist the forms of regulation imposed by the state and counter the discriminatory discourses which single-out families from non-EEA countries. In the vignette which followed, the forms of resistance shifted from those related to institutional discourses to those related to the intra-ethnic discrimination migrants face at work from within the migrants' community. The bottom-up view of ordinary members of those ethnic minorities who indirectly engage with the negative portrayals of the 'sham' marriage and the 'freshie' were explored through interview data where Usman described the ways he countered discriminatory discourses from inside his community. I found that the discursive strategies of migrants, identified by Holly and Meinhof as resistance discourses, appear in the localised context of everyday communicative action and not always at the institutional level of bureaucratic organisations (2013: 172). In the third vignette, resistance was action in the form of the vernacular literacies which migrants employ when generating and maintaining relationships across their extensive family relationships online. For the analysis of resistance, the types of cultural capital that the 'freshies' lack was contrasted with Usman's case where the analysis demonstrated that Usman's vernacular literacies provided him with the cultural 
capital he needed to both sustain old friendships in Mirpur while building new family relationships in Lancashire which set him apart from the 'uncool' freshie. Usman used all of the language varieties in his repertoires to reject the identities imposed on him and demonstrated his marriage was not a 'sham' by constructing new identities as a care-giver and step-father online.

Methodologically, the approach I took looked across settings, activities and individuals by investigating the ways in which discourses circulate and are recontextualised. By focusing on the institutional discourse of official rules and norms through which public bodies, such as the UKBA, articulate migration policies and laws in the first vignette I was able to demonstrate how institutional discourses are appropriated to get a visa. Then, by analysing observational data, interviews and Facebook postings I demonstrated how Usman constructs strategies which engage with anti-immigration discourses circulating both in his community (related to the 'freshie') and in the wider public sphere (related to 'sham' marriage), and showed how he moulds specific literacies in English to construct positive identities which resist some of the undesirable identities he faced at work. The findings endorse a critical approach to discourseethnographic work on discrimination which focuses attention on the question of what it means to claim a language as a resource and the detailed ways that language and literacy constitute valuable resources for expressing this resistance in online spaces and in the workplace.

\section{References}

Ahearn, L. (2012). Living language. An introduction to linguistic anthropology. Oxford: Wiley.

Baker, P., Gabrielatos, C., Khosravinik, M., Krzyzanowski, M., McEnery, A.M. and Wodak, R. (2008) A useful methodological synergy? Combining critical discourse analysis and corpus linguistics to examine discourses of refugees and asylum seekers in the UK press. Discourse and Society 19 (3), 273-306.

Ballard, R. (2008) The political economy of migration: Pakistan, Britain and the Middle East. In V S. Kalra (ed) Pakistani diasporas: Culture, conflict, and change (pp. 19-42). Oxford: Oxford University Press.

Barton, D. \& Hamilton, M. (2000) Literacy practices. In D. Barton, M. Hamilton and R. Ivanič (eds) Situated literacies: reading and writing in context (pp. 7-15). London: Routledge.

Bauman, R. and Briggs, C. (1990) Poetics and performance as critical perspectives on language and social life. Annual Review of Anthropology 19, 59-88. 
Baynham, M. and Masing, H.L. (2000) Mediators and mediation in multilingual literacy events. In K. Jones and M. Martin-Jones (eds) Multilingual literacies: Reading and writing different worlds (pp. 189-208). Amsterdam: John Benjamins.

Baynham, M. (1995) Literacy practices. London and New York: Longman.

Blackledge, A. \& Creese, A. (2010) Multilingualism. London: Continuum.

Blackledge, A. (2005) Discourse and power in a multilingual world. Amsterdam: John Benjamins.

Blommaert, J. (2005) Discourse: A Critical Introduction. Cambridge: Cambridge University Press.

Blommaert, J. (2012) The Sociolinguistics of Globalization. Cambridge: Cambridge University Press.

Bolognani, M. (2014) Visits to the Country of Origin: How Second-Generation British Pakistanis Shape Transnational Identity and Maintain Power Asymmetries. Global Networks 14 (1), 103-120.

Capstick, T. (2011). Language and migration: the social and economic benefits of learning English in Pakistan. In H. Coleman (Ed.), Dreams and realities: Developing countries and the English language (pp. 207-228). London: The British Council.

Capstick, T. (2016) Multilingual Literacies, Identities and Ideologies: Exploring Chain Migration from Pakistan to the UK. Basingstoke: Palgrave Macmillan.

Castells, M. (2009) Communication power. Oxford: Oxford University Press.

Charsley, K. (2005) Unhappy Husbands: Masculinity and Migration in Transnational Pakistani Marriages. Journal of the Royal Anthropological Institute 11, 85-105.

Charsley, K. and Bolognani, M. (2017) Being a Freshie is (not) Cool: stigma, capital and disgust in British Pakistani stereotypes of new subcontinental migrants. Ethnic and Racial Studies 40 (1), 43-62.

Chilton, P., Tian, H. and Wodak, R. (2010) Reflections on discourse and critique in China and the West. Journal of Language and Politics 9 (4), 489-507.

Coupland, N. (ed) (2010) Handbook of Language and Globalization. Malden, MA and Oxford: Wiley Blackwell. 
Department for Communities and Local Government (2009) The Pakistani Muslim Community in England: Understanding Muslim Ethnic Communities. DCLG: London

Duchene, A. Moyer, M. and Roberts, C. (2013) Introduction: Recasting institutions and work in multilingual and transnational spaces. In A. Duchene, M. Moyer and C. Roberts (eds) Language, Migration and Social Inequalities: A critical perspective on institutions and work (pp. 1-21). Bristol: Multilingual Matters.

Fairclough, N. (1992) Discourse and social change. Cambridge: Polity Press.

Goodhart, D. (2004). Too diverse? Prospect Magazine, 95, 30-37.

Kell, C. (2009). Literacy practices, text/s and meaning making across time and space. In M.

Baynham \& M. Prinsloo (eds), The future of literacy studies (pp. 75-99).

Basingstoke: Palgrave Macmillan.

Heller, M. (2010) Paths to Post-nationalism. Oxford: Oxford University Press.

Holly, W. and Meinhof, H. (2013) 'Integration hatten wir letztes Jahr'. Official discourses of integration and their uptake by migrants in Germany. In A. Duchene, M. Moyer and C. Roberts (eds) Language, Migration and Social Inequalities: A critical perspective on institutions and work (pp. 171-195). Bristol: Multilingual Matters.

Home Office (2001) Control of immigration: Statistics United Kingdom 2000. London: The Stationery Office.

Hussain, Y. and Bagguley, P. (2005) Citizenship, Ethnicity and Identity: British Pakistanis After the 2001 'riots'. Sociology 39 (3), 407-425.

Krzyżanowski, M. (2008) Analysing focus group discussions. In R. Wodak and M. Krzyżanowski (eds) Qualitative discourse analysis in the socials sciences (pp. 162-181). Basingstoke: Palgrave Macmillan.

Marcus, G. (2005) Ethnography in/of the world system: The emergence of multi-sited ethnography. Annual Review of Anthropology 24, 95-117.

McAuliffe, C. (2008) Transnationalism Within: Internal Diversity in the Iranian Diaspora. Australian Geographer 39 (1): 63-80.

Pyke, K. and Dang, T. (2003) 'FOB' and 'Whitewashed': Identity and Internalized Racism Among Second Generation Asian Americans. Qualitative Sociology 26 (2): 147-172. 
Reisigl, M. \& Wodak, R. (2009) The discourse-historical approach (DHA). In R. Wodak and M. Meyer (eds) Methods of Critical Discourse Analysis (2nd edn) (pp. 87-122). London: Sage.

Sabate i Dalmau, M. (2013) Fighting exclusion from the margins: Locutorios as Sites of Social Agency and Resistance for Migrants. In In A. Duchene, M. Moyer and C. Roberts (eds) Language, Migration and Social Inequalities: A critical perspective on institutions and work (pp. 248-271). Bristol: Multilingual Matters.

Sarangi, S. and Roberts, C. (eds) (1999) Talk, Work and Institutional Order: discourse in medical, mediation and management settings. Berlin: Mouton de Gruyter.

Shankar, S. (2008) Desi Land. Durham: Duke University Press.

Shaw, A. (1988) A Pakistani Community in Britain. Oxford: Blackwell.

van Dijk, T.A. (1984) Prejudice in Discourse. Amsterdam: Benjamins

Wodak, R. (1996) Disorders of discourse (Real language series). London: Longman.

Wodak, R. (2014) The European Parliament: Multilingual experiences in the everyday life of MEPs. In J.W. Unger, M. Krzyżanowski and R. Wodak (eds) Multilingual encounters in Europe’s institutional spaces (pp. 125-146). London: Bloomsbury Academic. 